\title{
Effect of the entomopathogenic nematode-bacterial symbiont complex on Meloidogyne hapla and Nacobbus aberrans in short-term greenhouse trials
}

\author{
Caccia Milena ${ }^{\mathrm{a}}$, Marro Nicolás ${ }^{\mathrm{b}}$, Rondan Dueñas Juanc, E. Doucet Marcelo ${ }^{\mathrm{a}}$, Lax Paola ${ }^{\mathrm{a}, *}$ \\ a Instituto de Diversidad y Ecología Animal (CONICET-UNC) and Centro de Zoología Aplicada, Facultad de Ciencias Exactas, Físicas y Naturales, Universidad Nacional de Córdoba, Rondeau 798, \\ X5000AVP, Córdoba, Argentina \\ ${ }^{\mathrm{b}}$ Instituto Multidisciplinario de Biología Vegetal (CONICET-UNC), X5000AVP, Córdoba, Argentina \\ ${ }^{\mathrm{c}}$ Laboratorio de Biología Molecular, Pabellón CEPROCOR, Santa María de Punilla, X5164, Córdoba, Argentina
}

\section{ARTICLE INFO}

\section{Keywords:}

Plant-parasitic nematodes

Biological control

Steinernema

Heterorhabditis

Photorhabdus

Xenorhabdus

\begin{abstract}
A B S T R A C T
Meloidogyne hapla and Nacobbus aberrans are plant-parasitic nematodes that form galls in the roots of infected plants and cause important economic losses. Entomopathogenic nematodes (EPNs) of the genera Steinernema and Heterorhabditis infect and kill insects via toxins produced by their symbiotic bacteria. EPNs have shown to have an antagonistic effect on different plant-parasitic nematode species in field and greenhouse trials. The aim of the present work was to evaluate, in tomato plants in greenhouse, the effect of the application of three Argentine EPN isolates, their symbiotic bacteria and cell-free supernatants, on a population of $M$. hapla and two populations of $N$. aberrans. Sixty days after inoculation, the number of galls and egg masses, the nematode reproduction factor (RF) and plant biomass were calculated. None of the plant-parasitic nematode populations or plant biomass was affected by infective juvenile inoculation of the different EPN isolates. Bacterial action differed among populations; $M$. hapla was the most susceptible one, with a significant reduction in the number of galls, egg masses and RF caused by the application of the three bacterial strains. The most significant effect was produced by the cell-free supernatants on nematode RF, with reductions of $62-90 \%$, caused by bacterial metabolites. The different inoculation alternatives of the EPN-bacterial symbiont complex tested in the present work (infective juveniles, bacteria and cell-free supernatant) are compared for the first time for plant-parasitic nematode species.
\end{abstract}

\section{Introduction}

Plant-parasitic nematodes cause great damage to crops and, therefore, are a limiting factor in agriculture (Archana and Prasad, 2014), generating worldwide economic annual losses that have been estimated at $\$ 173$ billion (Elling, 2013). In regions of tropical and sub-tropical climates, crop production losses caused by nematodes were estimated in $14.6 \%$ compared with $8.8 \%$ in developed countries (Nicol et al., 2011).

The root-knot nematode (Meloidogyne spp.) is one of the most damaging plant-parasitic nematodes in the world. This cosmopolitan genus comprises approximately 90 valid species (Jones et al., 2013); M. arenaria, $M$. hapla, $M$. javanica and $M$. incognita are polyphagous species that have the most severe effects on crops (Bent et al., 2008). On the other hand, the false root-knot nematode Nacobbus aberrans is native to the American continent and, to date, has been found in Argentina, Bolivia, Chile, Ecuador, USA, Mexico and Peru; it has quarantine importance and is characterized by a wide host range (EPPO, 2009).

\footnotetext{
* Corresponding author.

Email address: laxpaola@gmail.com (L. Paola)
}

Entomopathogenic nematodes (EPNs) of the genera Steinernema and Heterorhabditis infect and kill insects with the aid of toxins produced by their symbiotic bacteria. In Steinernema spp., bacteria belong to the genus Xenorhabdus whereas in Heterorhabditis, bacteria are of the genus Photorhabdus. The infective juvenile (IJ) enters the host and releases the bacteria in the hemocoel, where bacteria reproduce and kill the insect, generally within $48 \mathrm{~h}$ (Dillman et al., 2012). Bacteria produce cytolysin, hemolysin and toxins, some of which induce apoptosis or necrosis in the host cells (Nielsen Le-Roux et al., 2012).

Biological control for plant-parasitic nematodes management using antagonist microorganisms is an alternative to the application of chemical pesticides (Vagelas and Gowen, 2012). More than 30 years ago, an antagonism between plant-parasitic nematodes and EPNs was observed (Bird and Bird, 1986; Ishibashi and Kondo, 1986). EPNs have shown that effect in field and greenhouse trials on different species, such as Criconemoides spp., Belonolaimus longicaudatus (Grewal et al., 1997), Rotylenchulus reniformis (Lone et al., 2014), Globodera rostochiensis (Perry et al., 1998) and Meloidogyne spp. (Khan et al., 2010, 2016; Raza et al., 2015; Kepenekci et al., 2016); the best re- 
sults have been obtained with species of the latter genus (Lewis and Grewal, 2005). The application of IJs of different isolates has had a suppressive effect on Meloidogyne spp., both in the number of eggs (Pérez and Lewis, 2004) and egg masses (Kepenekci et al., 2016), and in the infection of second-stage juveniles (J2) in roots (Molina et al., 2007). Regarding $N$. aberrans, the only work conducted to date showed a reduction in nematode reproduction on tomato plants inoculated with IJs of $H$. bacteriophora and $S$. rarum (Caccia et al., 2013). Furthermore, the use of symbiotic bacteria and/or their metabolites has shown to have a nematicidal action against $\mathrm{J} 2$ of Meloidogyne spp. in vitro (Grewal et al., 1999; Hu et al., 1999; Aatif et al., 2012) as well as a reduction in host infection in greenhouse trials (Grewal et al., 1999; Sasnarukkit et al., 2002; Vyas et al., 2008; Kepenekci et al., 2016). Even in some treatments, the level of control was comparable to the chemical treatments (Vyas et al., 2008).

Some EPN isolates may be more effective against certain plant-parasitic nematode species, and some plant species may not be as attuned to the benefits of specific EPNs (Kenney and Eleftherianos, 2016). For this reason, it is important to consider new EPN isolates and compare the effect of different inoculation options of the nematode-bacterial symbiont complex. The aim of this work was to evaluate, under controlled conditions, the effect of the application of IJs of Argentine EPN isolates, as well as their symbiotic bacteria and metabolites, on M. hapla and $N$. aberrans populations and plant growth in tomato plants.

\section{Materials and methods}

\subsection{Nematodes and bacterial cultures}

The origin of the nematode species and symbiotic bacteria used are indicated in Table 1. Populations of N. aberrans and M. hapla were maintained on tomato plants (Solanum lycopersicum) cultivar Platense in a greenhouse. Egg masses were extracted from infected roots and placed in Petri dishes containing distilled water; they were kept at room temperature $\left(20 \pm 2{ }^{\circ} \mathrm{C}\right)$ until eggs hatched, and $\mathrm{J} 2$ were recovered with a pipette under stereoscopic microscope for inoculation. EPN isolates were multiplied on larvae of Galleria mellonella (Lepidoptera: Pyralidae), following the procedure described by Koppenhöfer (2007). IJs were collected using White traps (White, 1927) and maintained in water at $25 \pm 1{ }^{\circ} \mathrm{C}$ until use, for no longer than 21 days (Pérez and Lewis, 2004).

To obtain symbiotic bacteria, 100 IJs were surface sterilized in 5\% $\mathrm{NaClO}$ for $3 \mathrm{~min}$ and washed with sterile water. Externally sterilized nematodes were homogenized with a stick to release the symbiotic bacteria. A drop of the homogenate was streaked on to plates with brain-heart infusion agar as growth medium. Colonies were isolated after $48 \mathrm{~h}$ of incubation at $28^{\circ} \mathrm{C}$. Those colonies exhibiting uniform morphology and color were subcultured by incubating them at $25^{\circ} \mathrm{C}$ for $24 \mathrm{~h}$. Colonies were isolated and cultured in $50 \mathrm{ml}$ of brain-heart liquid medium, which was incubated for $48 \mathrm{~h}$ at $30^{\circ} \mathrm{C}$, with agitation at $150 \mathrm{rpm}$. Cultures were centrifuged at $20000 \mathrm{~g}$ for $20 \mathrm{~min}$ at $4^{\circ} \mathrm{C}$ and the supernatant was separated. The pellet was suspended in $50 \mathrm{ml}$ of sterile physiological solution (bacterial suspension). Optical density of bacterial sus-

Table 1

Origin of plant-parasitic nematodes, entomopathogenic nematodes and bacterial cultures involved in the present study.

\begin{tabular}{|c|c|c|}
\hline Nematodes/Bacteria & Code & $\begin{array}{l}\text { Locality (Department, } \\
\text { Provincia) }\end{array}$ \\
\hline
\end{tabular}

\section{Plant-parasitic nematode}

Meloidogyne hapla

$\begin{array}{ll}\text { LT } & \text { Las Tapias (San } \\ \text { Javier, Córdoba) }\end{array}$

Las Tapias (San

Nacobbus aberrans

LUL Lules (Lules,

Tucumán)

Río Cuarto (Río

Cuarto, Córdoba)

Entomopathogenic nematode/bacterial symbiont Heterorhabditis bacteriophora/

Photorhabdus luminescens

Steinernema sp./Xenorhabdus sp.

CBA

S. rarum/X. szentirmaii pension was measured, and based on calibration curves, it was diluted in physiological solution to obtain a concentration of $10^{6} \mathrm{CFU} /$ $\mathrm{ml}$; this dose has been used in similar experiments (Samaliev et al., 2000; Vagelas et al., 2007). Each supernatant containing metabolites was diluted in an equal proportion to that of its corresponding bacterial suspension and then passed through a $0.2-\mu \mathrm{m}$ mesh filter (Millipore) (cell-free supernatant).

\subsection{Experimental design}

Two experiments were conducted under controlled conditions in a greenhouse. Seeds of tomato cv Platense were germinated in plastic trays containing a mixture (3:1) of sterile soil and vermiculite (autoclaved at $1.5 \mathrm{~atm}$ for $30 \mathrm{~min}$ ). Soil physicochemical properties were as follows: organic matter $=4.06 \%$; organic carbon $=2.36 \%$; $\mathrm{N}=0.22 \%$; $\mathrm{P}=116.7 \mathrm{ppm} ; \mathrm{pH}=6.6$. After five weeks, seedlings with four true leaves were extracted and placed in plastic pots $(3.8 \mathrm{~cm}$ in diameter $\mathrm{x}$ $15 \mathrm{~cm}$ in height) containing $190 \mathrm{~g}$ sterilized soil and sand (3:1). Immediately after transplanting, for both experiments, $1.5 \mathrm{ml}$ of water containing $100 \mathrm{~J} 2$ were inoculated on roots (Initial population = Pi); then, they were covered with the same substrate. Immediately after inoculation, depending on the experiment, IJs, bacterial suspensions, or cell-free supernatants were applied on the surface soil in each pot, as follows. In the first experiment, the effects of IJs of each EPN isolate on the different plant-parasitic nematode populations were analyzed. In each treatment $(\mathrm{n}=7), 25 \mathrm{IJ} / \mathrm{cm}^{2}$ contained in a final volume of $4 \mathrm{ml}$ of water were inoculated with a pipette (Molina et al., 2007); this is the dose usually used for insect control in the field (Georgis and Hague, 1991). In the second experiment $(n=6), 4 \mathrm{ml}$ of the bacterial suspension $\left(10^{6} \mathrm{CFU} /\right.$ $\mathrm{ml}$ ) or of the cell-free supernatant, depending on the treatment, was applied. In both experiments, controls (plants inoculated only with the phytoparasitic nematode) were treated with the same amount of water or sterile culture medium (in the second experiment). The plants were grown at $25 \pm 1{ }^{\circ} \mathrm{C}$, with a 12 -h photoperiod; automatic irrigation was applied daily. After 60 days, the plants were uprooted and the roots were carefully washed to remove adhered soil particles. The number of galls and egg masses was counted under stereoscopic microscope. Egg masses were removed and immersed in a $1 \% \mathrm{NaClO}$ solution during $4 \mathrm{~min}$ to dissolve the gelatinous matrix (Hussey and Barker, 1973); the number of eggs was counted under light microscope. The soil of each pot was processed using the centrifugal-flotation technique (Jenkins, 1964) to obtain filiform individuals. For each replicate, the final population (Pf) of $N$. aberrans and M. hapla was calculated by summing the total number of eggs and the nematodes extracted from the soil; with these values, the reproduction factor was calculated $(\mathrm{RF}=\mathrm{Pf} / \mathrm{Pi})$. After making all the observations, the roots and the aerial part of each plant were dried in a heater to estimate biomass. Both experiments had a completely randomized design and were repeated twice.

\subsection{Data analysis}

The variables RF and biomass of tomato plants were analyzed using Mixed Models. The best model fitting heterogeneous variances was selected using the Akaike and Bayesian criteria (Zar, 1999). The number of galls and egg masses was analyzed using Generalized Linear Mixed Models, considering a Poisson distribution. In all cases, treatments and replications were defined as fixed and random effects, respectively. Means were compared using an a posteriori DGC test $(\mathrm{p} \leq 0.05)$. The analyses were performed using the software Infostat and its interface with the software R (Di Rienzo et al., 2013).

\section{Results}

The application of IJs on tomato biomass had different effects according to the plant-parasitic nematode population (Table 2). There were no differences in biomass between treatments and control for plants inoculated with $M$. hapla LT $(\mathrm{p}=0.34)$ or with $N$. aberrans LUL ( $\mathrm{p}=0.33$ ). In $N$. aberrans $\mathrm{RC}$, the highest biomass was recorded in the treatment with $H$. bacteriophora CBA ( $\mathrm{p}=0.0037)$. Furthermore, IJ inoculation did not have significant effects on any of the nema- 
Table 2

Tomato plant dry weight (g) 60 days after inoculation with Meloidogyne hapla, Nacobbus aberrans and infective juveniles of different entomopathogenic nematode isolates.

\begin{tabular}{|c|c|c|c|}
\hline Treatments & $\begin{array}{l}\text { M. hapla } \\
\text { LT }\end{array}$ & $\begin{array}{l}\text { N. aberrans } \\
\text { LUL }\end{array}$ & $\begin{array}{l}N . \\
\text { aberrans } \\
\text { RC }\end{array}$ \\
\hline Control & $1.5 \pm 0.9 \mathrm{a}$ & $2.4 \pm 1.3 a$ & $1.4 \pm 0.4 b$ \\
\hline Steinernema sp. LB & $1.6 \pm 0.7 \mathrm{a}$ & $2.3 \pm 0.9 \mathrm{a}$ & $1.7 \pm 0.7 b$ \\
\hline S. rarum RACA & $1.2 \pm 0.6 \mathrm{a}$ & $2.4 \pm 1.2 \mathrm{a}$ & $2.1 \pm 0.8 b$ \\
\hline $\begin{array}{l}\text { Heterorhabditis } \\
\text { bacteriophora CBA }\end{array}$ & $1.4 \pm 0.7 a$ & $1.8 \pm 0.6 \mathrm{a}$ & $2.7 \pm 1.4 \mathrm{a}$ \\
\hline
\end{tabular}

Data are a mean of 14 replicates. Columns with different letters are significantly different according to DGC test $(\mathrm{p} \leq 0.05)$.

AbbreviationsLT: Las Tapias, LUL: Lules, RC: Río Cuarto, LB: La Bolsa, RACA: Rama Caída, CBA: Córdoba.

$\mathrm{p}=0.06 ; N$. aberrans LUL: $\mathrm{p}=0.58 ; N$. aberrans RC: $\mathrm{p}=0.06)$, or RF $(M$. hapla LT: $\mathrm{p}=0.49 ;$. aberrans LUL: $\mathrm{p}=0.30 ; N$. aberrans $\mathrm{RC}: \mathrm{p}=0.75$ ) (data not shown).

The application of bacterial suspensions and cell-free supernatants did not affect the biomass (Table 3) of plants parasitized by M. hapla LT $(\mathrm{p}=0.80)$ or $N$. aberrans RC $(\mathrm{p}=0.40)$, whereas the biomass of tomato infected with $N$. aberrans LUL was increased by the bacterial suspension of Xenorhabdus sp. LB ( $\mathrm{p}=0.0008)$ and reduced by the supernatant of $P$. luminescens $\mathrm{CBA}(\mathrm{p}=0.0008)$. Regarding their effects on phytoparasitic nematodes (Table 4), the number of galls $(\mathrm{p}<0.0001)$ and egg masses ( $\mathrm{p}<0.0001$ ) was significantly reduced in all M. hapla LT treatments as well as the RF ( $p=0.005)$, whereas cell-free supernatants were the most efficient, especially that of Xenorhabdus sp. LB. In the N. aberrans LUL population, only bacterial suspension of $X$. szentirmaii RACA reduced the number of galls significantly ( $<<0.0001)$. The application of the three supernatants reduced the number of galls and egg masses, with $P$. luminescens CBA being the most efficient ( $\mathrm{p}<0.0001)$; RF was affected only by the latter supernatant and that of Xenorhabdus sp. LB ( $p=0.0016)$. For $N$. aberrans RC, bacterial suspension of Xenorhabdus sp. LB did not affect any variable with respect to control, whereas the remaining treatments with bacterial suspensions or supernatants reduced the number of galls ( $\mathrm{p}<0.0001)$ and egg masses $(\mathrm{p}<0.0001)$, with the supernatant of Xenorhabdus sp. LB being the most efficient. The three supernatants and the bacterial suspension of $P$. luminescens CBA reduced RF of $N$. aberrans RC population significantly ( $\mathrm{p}<0.0001)$.

\section{Discussion}

The antagonism between plant-parasitic nematodes and EPNs is of particular interest for two reasons: first, for the search of new alternatives to supplant or complement the use of chemical products to control nematode pests; sec-

Table 3

Tomato plant dry weight (g) 60 days after inoculation with Meloidogyne hapla, Nacobbus aberrans, symbiotic bacterial suspensions and their cell-free supernatants.

\begin{tabular}{llll}
\hline & $\begin{array}{l}\text { M. hapla } \\
\text { LT }\end{array}$ & $\begin{array}{l}\text { N. aberrans } \\
\text { LUL }\end{array}$ & $\begin{array}{l}\text { N. aberrans } \\
\text { RC }\end{array}$ \\
\hline $\begin{array}{l}\text { Control } \\
\text { Water }\end{array}$ & $1.8 \pm 0.7 \mathrm{a}$ & $3.6 \pm 1.0 \mathrm{~b}$ & $1.2 \pm 0.3 \mathrm{a}$ \\
$\begin{array}{l}\text { Culture medium } \\
\text { Bacterial suspension }\end{array}$ & $1.8 \pm 0.7 \mathrm{a}$ & $3.4 \pm 0.8 \mathrm{~b}$ & $1.1 \pm 0.3 \mathrm{a}$ \\
$\begin{array}{l}\text { Xenorhabdus sp. LB } \\
X . \text { szentirmaii }\end{array}$ & $1.8 \pm 0.7 \mathrm{a}$ & $5.7 \pm 1.7 \mathrm{a}$ & $1.3 \pm 0.5 \mathrm{a}$ \\
$\begin{array}{l}\text { RACA } \\
P . \text { luminescens CBA }\end{array}$ & $2.1 \pm 0.8 \mathrm{a}$ & $3.4 \pm 1.0 \mathrm{~b}$ & $1.7 \pm 0.7 \mathrm{a}$ \\
$\begin{array}{l}\text { Cell-free supernatant } \\
\text { Xenorhabdus sp. LB }\end{array}$ & $1.3 \pm 0.3 \mathrm{a}$ & $3.4 \pm 1.0 \mathrm{~b}$ & $1.5 \pm 0.7 \mathrm{a}$ \\
$\begin{array}{l}X \text {. szentirmaii } \\
\text { RACA }\end{array}$ & $1.6 \pm 0.7 \mathrm{a}$ & $3.5 \pm 2.0 \mathrm{~b}$ & $1.4 \pm 0.6 \mathrm{a}$ \\
$P$. luminescens CBA & $1.7 \pm 0.9 \mathrm{a}$ & $1.4 \pm 0.4 \mathrm{c}$ & $1.7 \pm 0.7 \mathrm{a}$ \\
\hline
\end{tabular}

Data are the mean of 14 replicates. Columns with different letters are significantly different according to DGC test ( $\mathrm{p} \leq 0.05)$.

Abbreviations. LT: Las Tapias, LUL: Lules, RC: Río Cuarto, LB: La Bolsa, RACA: Rama Caída, CBA: Córdoba. ondly, the fact that NEPs are already commercially available for the control of insect pests in various countries (Said et al., 2015). This work analyzed the effect of the application of IJs, symbiotic bacteria and cell-free supernatants of EPNs on Argentine populations of N. aberrans and M. hapla, as well as on the biomass of host plants. No previous studies have compared the different inoculation possibilities of the EPN-bacterial symbiont complex tested in the present study on plant-parasitic nematodes.

Most of the studies conducted to date have used the direct application of IJs in aqueous suspension and, in some cases, it had an antagonistic effect on different phytoparasitic nematode species (Pérez and Lewis, 2002; Molina et al., 2007; Maru et al., 2001, 2013; Aatif et al., 2012; Caccia et al., 2013). However, EPNs may not have the same effect on all nematodes (Lewis and Grewal, 2005) and, occasionally, this reduction has not proven to be effective (Fallon et al., 2002; LaMondia and Cowles, 2002; Nyczepir et al., 2004). This finding is in agreement with our present observations, since none of the $N$. aberrans or M. hapla populations was affected by IJ inoculation of the different EPN isolates tested. In a previous study in our laboratory, in tomato plants, we found that IJs of $H$. bacteriophora and $S$. rarum reduced the multiplication of a $N$. aberrans population by 53 and 57\%, respectively; however, the number of galls and egg masses was not reduced (Caccia et al., 2013). This divergence in the results could be caused by differences between the EPN isolates tested, since they had a different origin than those used in the present work. Pérez and Lewis (2004) applied $25 \mathrm{JI} / \mathrm{cm}^{2}$ of $S$. feltiae and $S$. riobrave and observed a reduction in penetration of $\mathrm{J} 2 \mathrm{M}$. incognita and M. hapla in peanut (Arachis hypogaea) roots, while IJs of $H$. bacteriophora did not produce that effect. Those authors explained this since species of Steinernema, but not $H$. bacteriophora, could enter the roots releasing their bacteria. This difference was not observed in our study. Kepenekci et al. (2016) neither observed divergences between genera of EPNs, both reduced egg masses of Meloidogyne spp. in tomato using the same dose than in the present study. Furthermore, in the present work, EPNs did not affect tomato plant biomass, except for the interaction between $N$. aberrans RC and IJs of $H$. bacteriophora CBA, which produced a $92 \%$ increase in tomato dry weight. Previous studies involving IJs of different EPN species have shown inconsistent results in their effects on plant dry weight (Fallon et al., 2002; Shapiro-Ilan et al., 2006) as well as increases in biomass (Hussaini et al., 2009; Maru et al., 2001, 2013).

The application of bacteria and/or their supernatants have shown the highest antagonistic effect on plant-parasitic nematodes (Vyas et al., 2008; Aatif et al., 2012; Kepenekci et al., 2016). Here, the action of bacterial suspensions differed among populations; $M$. hapla LT was the most susceptible, showing a significant reduction in the number of galls (51-67\%), egg masses (48-68\%) and RF (55-62\%) after the application of the bacterial strains. In $N$. aberrans, $X$. szentirmaii RACA reduced the number of galls by $21 \%$ (LUL) and $28 \%$ (RC), and of egg masses by $25 \%$ (only in RC), whereas $P$. luminescens CBA induced a significant reduction in galls (23\%), egg masses (47\%) and RF (63\%) of $\mathrm{RC}$ population. In a greenhouse experiment, the number of Meloidogyne spp. females in tomato roots treated with $10^{3}$ and $10^{6}$ cell/ml suspensions of Pseudomonas oryzihabitans (associated with Steinernema abassi), decreased by $22 \%$ and $82 \%$, respectively (Vagelas et al., 2007). In addition, a reduction in egg masses caused by those treatments was reported. While Xenorhabdus sp. LB bacterial suspension did not have a significant effect on $\mathrm{N}$. aberrans, the application of its supernatant proved to be efficient in reducing the nematodes variables. Here, the most significant effect of the three supernatants was observed on nematode multiplication, with reductions that ranged between $62 \%(N$. aberrans RC) and 90\% (M. hapla LT). No previous studies have evaluated the effect of the application of cell-free supernatants of symbiotic bacteria on the reproduction of plant-parasitic nematodes. However, in studies with supernatants of EPN bacterial symbionts, a decrease in host root penetration of Meloidogyne spp. (Grewal et al., 1999; Sasnarukkit et al., 2002) or a reduction in the gall index (Vyas et al., 2008) were observed. Furthermore, Kepenekci et al. (2016) tried different inoculum options (IJs of $\mathrm{H}$. bacteriophora and Steinernema spp., infected cadavers of insect larvae and cell-free supernatants of their symbiotic bacteria) and found than the supernatant treatment was the most effective option. Nevertheless, these authors did not specify the concentra- 
Table 4

Effect of the application of symbiotic bacterial suspensions and their cell-free supernatants on populations of Meloidogyne hapla and Nacobbus aberrans in tomato plants.

\begin{tabular}{|c|c|c|c|c|c|c|c|c|c|}
\hline \multirow[t]{2}{*}{ Treatments } & \multicolumn{3}{|l|}{ M. hapla LT } & \multicolumn{3}{|l|}{ N. aberrans LUL } & \multicolumn{3}{|l|}{ N. aberrans RC } \\
\hline & Galls & Egg masses & $\mathrm{RF}$ & Galls & Egg masses & $\mathrm{RF}$ & Galls & Egg masses & $\mathrm{RF}$ \\
\hline \multicolumn{10}{|l|}{ Control } \\
\hline Culture medium & $40.8 \pm 28.1 \mathrm{a}$ & $24.1 \pm 15.3 \mathrm{a}$ & $57.7 \pm 21.8 \mathrm{a}$ & $36.8 \pm 12.2 \mathrm{a}$ & $10.0 \pm 3.0 \mathrm{a}$ & $25.2 \pm 5.8 \mathrm{a}$ & $47.0 \pm 10.3 \mathrm{a}$ & $18.2 \pm 3.8 \mathrm{a}$ & $37.1 \pm 16.4 \mathrm{a}$ \\
\hline \multicolumn{10}{|l|}{ Bacterial suspension } \\
\hline Xenorhabdus sp. LB & $19.4 \pm 10.2 \mathrm{~b}$ & $12.5 \pm 6.2 \mathrm{~b}$ & $25.6 \pm 14.8 b$ & $31.6 \pm 7.5 \mathrm{a}$ & $9.3 \pm 5.4 a$ & $24.4 \pm 13.9 \mathrm{a}$ & $47.0 \pm 10.3 a$ & $18.8 \pm 7.0 \mathrm{a}$ & $53.1 \pm 21.1 \mathrm{a}$ \\
\hline X. szentirmaii RACA & $14.0 \pm 7.5 c$ & $8.7 \pm 1.7 c$ & $21.5 \pm 7.5 b$ & $26.6 \pm 13.6 \mathrm{~b}$ & $8.8 \pm 6.1 \mathrm{a}$ & $17.8 \pm 14.2 \mathrm{a}$ & $37.3 \pm 10.3 b$ & $12.8 \pm 4.1 \mathrm{~b}$ & $27.2 \pm 16.7 \mathrm{a}$ \\
\hline P. luminescens CBA & $13.3 \pm 8.0 \mathrm{c}$ & $7.6 \pm 5.0 c$ & $22.7 \pm 10.2 b$ & $35.1 \pm 11.4 a$ & $9.6 \pm 4.5 \mathrm{a}$ & $21.9 \pm 8.9 \mathrm{a}$ & $36.3 \pm 14.5 b$ & $9.0 \pm 4.0 \mathrm{c}$ & $13.7 \pm 8.8 \mathrm{~b}$ \\
\hline Xenorhabdus sp. LB & $2.9 \pm 2.4 \mathrm{e}$ & $2.3 \pm 1.9 \mathrm{e}$ & $5.7 \pm 2.4 c$ & $26.1 \pm 13.6 \mathrm{~b}$ & $5.2 \pm 2.6 b$ & $5.9 \pm 4.2 b$ & $12.3 \pm 4.4 \mathrm{~d}$ & $2.5 \pm 1.8 \mathrm{e}$ & $9.5 \pm 8.6 b$ \\
\hline X. szentirmaii RACA & $8.4 \pm 7.5 \mathrm{~d}$ & $5.4 \pm 3.6 \mathrm{~d}$ & $10.9 \pm 9.0 \mathrm{c}$ & $26.6 \pm 12.0 \mathrm{~b}$ & $4.8 \pm 4.2 \mathrm{~b}$ & $13.8 \pm 10.3 \mathrm{a}$ & $20.0 \pm 8.7 c$ & $5.0 \pm 3.1 \mathrm{~d}$ & $14.1 \pm 9.7 \mathrm{~b}$ \\
\hline P. luminescens CBA & $9.0 \pm 7.5 \mathrm{~d}$ & $7.5 \pm 6.6 c$ & $9.9 \pm 7.1 \mathrm{c}$ & $8.3 \pm 6.5 c$ & $2.3 \pm 1.8 \mathrm{c}$ & $5.8 \pm 4.1 \mathrm{~b}$ & $23.5 \pm 16.4 c$ & $5.3 \pm 3.1 \mathrm{~d}$ & $13.8 \pm 7.9 \mathrm{~b}$ \\
\hline
\end{tabular}

Data are the mean of 14 replicates (average per root). Columns with different letters are significantly different according to the DGC test $(\mathrm{p} \leq 0.05)$.

Abbreviations. LT: Las Tapias, LUL: Lules, RC: Río Cuarto, LB: La Bolsa, RACA: Rama Caída, CBA: Córdoba. RF: reproduction factor. 
it difficult to compare the effectiveness of those isolates with the ones we analyzed.

In the present work, the application of bacteria and their supernatants had no significant influence on plant biomass, except in tomato infected with $N$. aberrans LUL, in which biomass decreased with the supernatant of $P$. luminescens $\mathrm{CBA}$ and increased with the bacterial suspension of Xenorhabdus sp. LB. This last result agrees with previous findings showing increases of biomass with the application of cell-free supernatants of different isolates of EPN bacteria (Vyas et al., 2008; Kepenekci et al., 2016). The latter authors attributed this effect, at least partially, to a decrease in plant-nematode infection rate. However, care must be taken when comparing plant growth parameters since there may be a fertilizer effect of the bacterial culture medium treatments (Kepenekci et al., 2016). Also, Vyas et al. (2008) drenched the roots as an application method, which could have produced more effective results on the plants. Besides, the original concentration of the medium culture from which they obtained the supernatant was nor specified in that work.

While the three supernatants had a considerable activity on $N$. aberrans and M. hapla, those corresponding to Xenorhabdus sp. LB and $P$. luminescens CBA were the most efficient, possibly due to the metabolites produced by those bacteria. Strains of Xenorhabdus spp. and Photorhabdus spp. produce several metabolites, some of which have insecticidal (Bowen et al., 1998; Yang et al., 2006; Nielsen Le-Roux et al., 2012; Castagnola and Stock, 2014), antifungal (Eleftherianos et al., 2007; Houard et al., 2013), antibiotic (Li et al., 1995; Ji et al., 2004; Morales-Soto and Forst, 2011; Song et al., 2011) and antiparasitic activity (Nollmann et al., 2012). So far, however, the only metabolites identified as having nematicidal activity are indole derivatives and hydroxystilbene produced by P. luminescens (Hu et al., 1999) and ammonia by Xenorhabdus spp. (Grewal et al., 1999). Other studies evidenced in vitro a nematicidal (Grewal et al., 1999; Sasnarukkit et al., 2002; Maru et al., 2001) or nematostatic effect (Aatif et al., 2012) on J2 Meloidogyne spp.

The fact that most nematicidal activity was recorded in cell-free supernatants might be beneficial in economic terms, since in vitro bacterial production is more cost-efficient and easier than that of EPN or the application of infested cadavers; in turn, it would involve less transportation, durability and formulation problems (Kepenekci et al., 2016). Efforts to identify the bacterial metabolite/s that would have nematicidal effect should be encouraged. Furthermore, additional research is still needed to determine their efficacy, especially under field conditions.

\section{Acknowledgements}

This work was financially supported by the Consejo Nacional de Investigaciones Científicas y Técnicas (PIP N11220150100235).

\section{References}

Aatif, H.M., Javed, N., Khan, S.A., Ahmed, S., 2012. Virulence of Xenorhabdus and Photorhabdus bacteria and their toxins against juvenile's immobilization of Meloidogyne incognita. Pakistan. J. Phytopathol 24, 170-174.

Archana, U.S., Prasad, D., 2014. Management of plant-parasitic nematodes by the use of botanicals. Journal of Plant Physiology and Pathology 2, 1-10.

Bent, E., Loffredo, A., McKenry, M.V., Becker, J.O., Borneman, J., 2008. Detection and investigation of soil biological activity against Meloidogyne incognita. J. Nematol. 40, 109-118.

Bird, A.F., Bird, J., 1986. Observations on the use of insect parasitic nematodes as means of biological control of root-knot nematodes. Int. J. Parasitol. 16, 511-516.

Bowen, D., Rocheleau, T.A., Blackburn, M., Andreev, O., Golubeva, E., Bhartia, R., Ffrench-Constant, R.H., 1998. Insecticidal toxins from the bacterium Photorhabdus luminescens. Science 280, 2129-2132.

Caccia, M.G., Lax, P., Doucet, M.E., 2013. Effect of entomopathogenic nematodes on the plant-parasitic nematode Nacobbus aberrans. Biol. Fertil. Soils 49, 105-109.

Castagnola, A., Stock, P., 2014. Common virulence factors and tissue targets of entomopathogenic bacteria for biological control of lepidopteran pests. Insects 5, 139-166.

Di Rienzo, J.A., Casanoves, F., Balzarini, M.G., Gonzalez, L., Tablada, M., Robledo, C.W., 2013. Grupo InfoStat, FCA. Universidad Nacional de Córdoba, Argentina, URL http:// www.infostat.com.ar.

Dillman, A.R., Chaston, J.M., Adams, B.J., Ciche, T.A., Goodrich-Blair, H., Adler, R., Stock, P., Sternberg, P.W., 2012. An entomopathogenic nematode by any other name. PLoS Pathog. 8, 1-4.

Eleftherianos, I., Boundy, S., Joyce, S.A., Aslam, S., Marshall, J.W., Cox, R.J., Simpson, T.J., Clarke, D.J., Ffrench-Constant, R.H., Reynolds, S.E., 2007. An antibiotic produced by an insect-pathogenic bacterium suppresses host defenses through phenoloxidase inhibition. Procedures of the National Academy of Science USA 104, 2419-2424.
Elling, A.A., 2013. Major emerging problems with minor Meloidogyne species. Phytopathology 103, 1092-1102.

EPPO, 2009. Nacobbus aberrans sensu lato. EPPO Bull. 39, 376-381.

Fallon, D.J., Kaya, H.K., Gaugler, R., Sipes, B.S., 2002. Effects of entomopathogenic nematodes on Meloidogyne javanica on tomatoes and soybeans. J. Nematol. 34, 239-245.

Georgis, R., Hague, N.G.M., 1991. Nematodes as biological insecticides. Pestic. Outlook 2, 29-32.

Grewal, P.S., Martin, W.R., Miller, R.W., Lewis, E.E., 1997. Suppression of plant-parasitic nematode populations in turfgrass by application of entomopathogenic nematodes. Biocontrol Sci. Technol. 7, 393-399.

Grewal, P.S., Lewis, E., Venkatachari, S., 1999. Allelopathy: a possible mechanism of suppression of plant parasitic nematodes by entomopathogenic nematodes. Nematology 1, 725-743.

Houard, J., Aumelas, A., Noël, T., Pages, S., Givaudan, A., Fitton-Ouhabi, V., Villain-Guillot, P., Gualtieri, M., 2013. Cabanillasin, a new antifungal metabolite, produced by entomopathogenic Xenorhabdus cabanillasii JM26. J. Antibiot. 66, 617-620.

Hu, K., Jianxiong, L., Webster, J.M., 1999. Nematicidal metabolites produced by Photorhabdus luminescens (Enterobacteriaceae), bacterial symbiont of entomopathogenic nematodes. Nematology 1, 457-469.

Hussaini, S.S., Kumar, K.C.K., Adholeya, A., Shakeela, V., 2009. Interaction effect of Steinernema spp. and arbuscular mycorhizal fungus, Glomus intraradices on the development and reproduction of Meloidogyne incognita (Kofoid and White) Chitwood in tomato. Trends in Biosciences 2, 33-36.

Hussey, R.S., Barker, K.R., 1973. A comparison of methods of collecting inocula of Meloidogyne spp., including a new technique. Plant Dis. Rep. 57, 1025-1028.

Ishibashi, N., Kondo, E., 1986. Steinernema feltiae (DD-136) and S. glaseri: persistence in soil and bark compost and their influence on native nematodes. J. Nematol. 18, 310-316.

Jenkins, W.R., 1964. A rapid centrifugal-flotation technique for separating nematodes from soil. Plant Dis. Rep. 48, 692.

Ji, D., Yi, Y., Kang, G.H., Choi, Y.H., Kim, P., Baek, N.I., Kim, Y., 2004. Identification of an antibacterial compound, benzylideneacetone, from Xenorhabdus nematophila against major plant-pathogenic bacteria. FEMS (Fed. Eur. Microbiol. Soc.) Microbiol. Lett. 239, 241-248.

Jones, J.T., Haegeman, A., Danchin, E.G.J., Gaur, H.S., Helder, J., Jones, M.G.K., Kikuchi, T., Manzanilla-López, R., Palomares-Rius, J.E., Wesemael, W.M.L., Perry, R., 2013. Top 10 plant-parasitic nematodes in molecular plant pathology. Mol. Plant Pathol. https://doi.org/10.1111/mpp.12057.

Kenney, E., Eleftherianos, I., 2016. Entomopathogenic and plant pathogenic nematodes as opposing forces in agriculture. Int. J. Parasitol. 46, 13-19.

Kepenekci, I., Hazir, S., Lewis, E.E., 2016. Evaluation of entomopathogenic nematodes and the supernatants of the in vitro culture medium of their mutualistic bacteria for the control of the root-knot nematodes Meloidogyne incognita and M. arenaria. Pest Manag. Sci. 72, 327-334, 4.

Khan, S.A., Javed, N., Kamran, M., Abbas, H., Safdar, A., Haq, I.U., 2016. Management of Meloidogyne incognita Race 1 through the use of entomopathogenic nematodes in tomato. Pakistan J. Zool. 48, 763-776.

Khan, M.R., Mehboob, A., Khan, U., 2010. Interaction of the entomopathogenic nematode Steinernema masoodi and the root-knot nematode Meloidogyne incognita on tomato. Nematol. Mediterr. 38, 179-185.

Koppenhöfer, A., 2007. Nematodes. In: Lacey, L.A., Kaya, H.K. (Eds.), Field Manual of Techniques in Invertebrate Pathology. Springer, pp. 249-264.

LaMondia, J.A., Cowles, R.S., 2002. Effects of entomopathogenic nematodes and Trichoderma harzianum on the strawberry black root rot pathogens Pratylenchus penetrans and Rhizoctonia fragariae. J. Nematol. 34, 351-357.

Lewis, E.E., Grewal, P.S., 2005. Interactions with plant-parasitic nematodes. In: Grewal, P.S., Ehlers, R.U., Shapiro-Ilan, D.I. (Eds.), Nematodes as Biocontrol Agents. CABI, pp. 349-362.

Li, J., Chen, G., Webster, J.M., 1995. Antimicrobial metabolites from a bacterial symbiont. J. Nat. Prod. 58, 1081-1086.

Lone, J.A., Ghazala, P., Khan, T.A., 2014. Comparison of concomitant and sequential inoculation of Steinernema sp. in the management of reniform (Rotylenchulus reniformis) nematode infecting eggplant. E-journal of Science \& Technology 2, 97-111.

Maru, A.K., Siddiqui, A.U., Parihar, A., Sharma, S.K., 2001. Bioefficacy of different populations of Steinernema carpocapsae against root knot nematode Meloidogyne incognita. J. Prog. Agric 2, 74-76.

Maru, A.K., Siddiqui, A.U., Parihar, A., Sharma, S.K., Srivastva, A.S., 2013. Effect of different formulations of entomopathogenic nematode Steinernema carpocapsae against root knot nematode Meloidogyne incognita on tomato. Indian Phytopathol. 66, 413-415.

Molina, J., Dolinsky, C., Souza, R.M., Lewis, E.E., 2007. Effect of entomopathogenic nematodes (rhabditida: steinernematidae and heterorhabditidae) on Meloidogyne mayaguensis rammah and hirschmann (tylenchida: meloidogynidae) infection in tomato plants. J. Nematol. 39, 338-342.

Morales-Soto, N., Forst, S., 2011. The xnp1 P2-like tail synthesis gene cluster encodes xenorhabdicin and is required for interspecies competition. J. Bacteriol. 193, 3624-3632.

Nicol, J.M., Turner, S.J., Coyne, D.L., den Nijs, L., Hockland, S., Maafi, Z.T., 2011. Current nematode threats to world agriculture. In: Jones, J.T., Gheysen, G., Fenoll, C. (Eds.), Genomics and Molecular Genetics of Plant-nematode Interactions. Springer, pp. 21-44.

Nielsen-LeRoux, C., Gaudriault, S., Ramarao, N., Lereclus, D., Givaudan, A., 2012. How the insect pathogen bacteria Bacillus thuringiensis and Xenorhabdus/Photorhabdus occupy their hosts. Curr. Opin. Microbiol. 15, 220-231.

Nollmann, F.I., Dowling, A., Kaiser, M., Deckmann, K., Grösch, S., Ffrench-Constant, R., Bode, H.B., 2012. Synthesis of szentiamide, a depsipeptide from entomopathogenic Xenorhabdus szentirmaii with activity against Plasmodium falciparum. Beilstein J. Org. Chem. 8, 528-533.

Nyczepir, A., Shapiro-Ilan, D.I., Lewis, E.E., Handoo, Z., 2004. Effect of entomopathogenic 
Perry, R.N., Hominick, W.M., Beane, J., Briscoe, B., 1998. Effect of entomopathogenic nematodes, Steinernema feltiae and S. carpocapsae, on the potato cyst nematode, Globodera rostochiensis, in pot trials. Biocontrol Sci. Technol. 8, 175-180.

Raza, M.S., Imran, M., Yasmin, T., Azeem, M., Manzoor, H., Awais, M., 2015. Screening of entomopathogenic nematodes for the management of Meloidogyne incognita in brinjal. Int. J. Biosci. 6, 19-31.

Said, R., Hix, R.L., Reitz, S., 2015. Biological control of grape root borer (Lepidoptera: sesiidae) with commercially available entomopathogenic nematodes in Florida Muscadine and 'Cynthiana' grapes. J. Entomol. Sci. 50, 150-156.

Samaliev, H.Y., Andreoglou, F.I., Elawad, S.A., Hague, N.G.M., 2000. The nematicidal effects of the bacteria Pseudomonas oryzihabitans and Xenorhabdus nematophilus on the root knot nematode Meloidogyne javanica. Nematology 2, 507-514.

Sasnarukkit, A., Gaugler, R., Sontirat, S., 2002. Effects of entomopathogenic nematode Steinernema siamkayai and its bacterial symbiont on Meloidogyne incognita. Int. J. Nematol. 12, 169-174.

Shapiro-Ilan, D.I., Nyczepir, A., Lewis, E., 2006. Entomopathogenic nematodes and bacteria applications for control of the pecan root-knot nematode, Meloidogyne partityla, in the greenhouse. J. Nematol. 38, 449-454.
Song, C.J., Samyeol, S., Sony, S., Yonggyun, K., 2011. Bacterial metabolites of an entomopathogenic bacterium, Xenorhabdus nematophila, inhibit a catalytic activity of phenoloxidase of the diamondback moth, Plutella xylostella. J. Microbiol. Biotechnol. 21, 317-322

Vagelas, I.K., Pembroke, B., Gowen, S.R., Davies, K.G., 2007. The control of root-knot nematodes (Meloidogyne spp.) by Pseudomonas oryzihabitans and its immunological detection on tomato roots. Nematology 9, 363-370.

Vagelas, I., Gowen, S.R., 2012. Control of Fusarium oxysporum and root-knot nematodes (Meloidogyne spp.) with Pseudomonas oryzihabitans. J. Phytopathol. 24, 32-38.

Vyas, R.V., Patel, B., Maghodia, A., Patel, D.J., 2008. Significance of metabolites of native Xenorhabdus, a bacterial symbiont of Steinernema, for suppression of collar rot and root knot diseases of groundnut. Indian J. Biotechnol. 7, 371-373.

White, G.F., 1927. A method for obtaining infective nematode larvae from cultures. Science 66, 302-303.

Yang, G., Dowling, J.A., Gerike, U., Ffrench-Constant, R.H., Waterfield, N.R., 2006. Photorhabdus virulence cassettes confer injectable insecticidal activity against the wax moth. J. Bacteriol. 188, 2254-2261.

Zar, J.H., 1999. Biostatistical Analysis, fourth ed. Prentice Hall. 